Riwayat Artikel: Diterima 23 April 2017; Direvisi 14 Juli 2017; Disetujui 18 Juli 2017; dan Dipublikasikan 26 Juli 2017

\title{
ANALISIS WACANA KRITIS PADA PEMBERITAAN TEMPO.CO TENTANG KEMATIAN TARUNA STIP JAKARTA
}

\section{CRITICAL DISCOURSE ANALYSIS AT TEMPO.CO ON THE NEWS ABOUT THE DEATH OF TARUNA STIP JAKARTA}

\author{
Genta Maghvira \\ (genta@unissula.ac.id) \\ (Program Studi Ilmu Komunikasi, Fakultas Bahasa dan Ilmu Komunikasi, UNISSULA)
}

\begin{abstract}
Abstrak
Tujuan penelitian ini untuk mengetahui analisis wacana kritis dari pemberitaan tentang kematian taruna STIP yang dipublikasikan Tempo.co. Dalam penelitian ini dicermati segala aspek mikrostruktural, mesostruktural dan makrostruktutal yang dikembangkan untuk memproduksi teks berita. Penelitian ini menggunakan satu berita dari Tempo.co dengan judul 'Taruna STIP Tewas Dihajar Senior, Ini Kronologinya,' terbit 11 Januari 2017 secara online. Penelitian ini menggunakan model analisis wacana kritis Norman Fairclough. Metodologi kualitatif digunakan sebagai dasar berpikir, dan paradigma kritis digunakan sebagai sudut pandang penelitian. Hasil penelitian menunjukkan, Tempo.co melakukan praktik pemilihan diksi, penggunaan kalimat luas sebab akibat, dan pemilihan narasumber dalam kutipan langsung untuk memproduksi teks berita. Realisasi teks yang dihasilkan Tempo.co dalam pemberitaan tersebut juga dinilai selaras dengan misi-nya yaitu menghasilkan produk multimedia yang independen dan bebas dari segala tekanan. Ada motivasi dalam produksi teks berita tersebut, yakni pembaca digiring untuk memberikan pencitraan positif pada Tempo.co sebagai media yang aktif dan eksis dalam menyuarakan keadilan.
\end{abstract}

Kata Kunci: Pemberitaan Media Online, Tempo.co, Analisis Wacana Kritis

\begin{abstract}
The purpose of this research is to know critical discourse analysis of the news about the death of taruna STIP that Tempo.co has been published. This research notice all of the aspects such as microstructure, meso-structure, and macrostructure. This research uses a news from Tempo.co with title 'Taruna STIP Tewas Dihajar Senior, Ini Kronologinya,' online published in January $11^{\text {th }} 2017$. This research uses Norman Fairclough's critical discourse analysis model. Qualitative method has been used as basic thinking and critical paradigm as research standpoint. The result shows that Tempo.co does an election diction; use of the causation phrase; and selecting resource in direct quotation. Realization of the result rates in line with the Tempo.co's company mission. Which is to create an independent multimedia product that free from any pressure. There was a motivation in news produced which lead the reader to give a positive sight for Tempo.co.
\end{abstract}

Keywords: Online News, Tempo.co, Critical Discourse Analysis

\section{Pendahuluan}

Kekerasan di lingkungan Lembaga Pendidikan Tinggi Kedinasan terjadi kembali dalam kasus kematian seorang taruna STIP (Sekolah Tinggi Ilmu Pelayaran) pada pekan kedua Januari 2017. Kekerasan yang dialami Amirullah Adityas Putra, asal Kecamatan Tanjung Priok, hingga menewaskannya, menjadi headline di media massa baik cetak, elektronik dan online. Tidak hanya berita yang disajikan, beberapa media memuat artikel tentang kekerasan dalam sekolah tinggi semi-militer tersebut.

Kasus ini bukan baru pertama kali terjadi, pada tahun 2007 di STPDN (Sekolah Tinggi Pendidikan Dalam Negeri) seorang praja bernama Cliff Muntu tewas karena 48 kekerasan yang ia terima dari seniornya. Kematian Cliff Muntu disiarkan secara nasional hingga akhirnya internal STPDN berbenah diri. Kini dengan kematian Amirullah Adityas 
Putra, ternyata kekerasan dalam Lembaga Pendidikan Tinggi Kedinasan masih terjadi tepat sepuluh tahun kemudian.

Kekerasan yang diterima korban Amirullah terjadi dengan kronologi sebagai berikut; pada selasa malam 10 Januari 2017 pukul 22.00 WIB, empat pelaku memanggil korban Amirullah dan lima orang junior lainnya. Keempat orang itu adalah Sisko Mataheru, Willy Hasiholan, Iswanto dan Akbar Ramadhan. Keempat pelaku melakukan penganiayaan terhadap korban dengan cara pemukulan di area perut, ulu hati dan bagian dada dengan tangan kosong. Tindakan kekerasan tersebut terjadi di Lantai 2 kamar M-205, Gedung Dermotery 4, STIP Jakarta.

Keempat pelaku memukuli korban secara bergantian hingga tiba giliran Willy Hasiholan memukul, namun korban terjatuh dan tidak sadarkan diri. Dengan panik, keempat pelaku membawa korban Amirullah ke atas tempat tidur, dan membaringkannya. Keempat pelaku sempat melapor pada senior dan beberapa waktu kemudian datang dokter untuk memeriksa namun dokter menyatakan bahwa Amirullah sudah meninggal. Sementara lima korban lain masih dalam kondisi kesakitan dan kelelahan. Sebelum kejadian tersebut, diketahui bahwa korban Amirullah dan beberapa teman yang lain baru melakukan sesi latihan marching band.

Berita dengan cepat menyebar dan kini masyarakat kembali diingatkan pada momen kematian-kematian siswa Lembaga Pendidikan Tinggi Kedinasan yang lalu. Bahwa ternyata, sampai dengan tahun 2017, budaya kekerasan struktural dari senior ke junior masih mengakar kuat, bahkan terus terjadi. Hal ini menjadi ironi tersendiri dalam dunia pendidikan. Bagaimana sebuah instansi yang seharusnya mencetak generasi yang lebih baik justru mencetak generasi yang akrab dengan kekerasan, pemukulan, dan senioritas. Bukan tidak mungkin jika kedepannya, para siswa tersebut justru tumbuh menjadi generasi yang penakut atau generasi yang menganggap kekerasan sebagai suatu kewajaran. Konsep ini jelas bertentangan dengan inti pendidikan itu sendiri.

Menurut UU No. 20 tahun 2003 Pendidikan adalah usaha sadar dan terencana untuk mewujudkan suasana belajar dan proses pembelajaran agar peserta didik secara aktif mengembangkan potensi dirinya untuk memiliki kekuatan spiritual keagamaaan, pengendalian diri, kepribadian, kecerdasan, akhlak mulia, serta ketrampilan yang diperlukan dirinya, masyarakat, bangsa, dan negara.

Menurut Ki Hajar Dewantara, pendidikaan adalah menuntun segala kekuatan kodrat yang ada pada anak-anak, agar mereka sebagai manusia dan sebagai anggota masyarakat dapat mencapai keselamatan dan kebahagiaan setinggitingginya.

Keselamatan nampaknya menjadi aspek yang kurang bisa dijamin oleh Sekolah Tinggi Ilmu Pelayaran. Karena justru di sekolah itulah salah satu siswa dinyatakan tidak selamat dan tidak tertolong lagi nyawanya akibat kekerasan yang sayangnya dilakukan oleh mereka yang secara umur dan secara pendidikan, sudah jauh diatas korban.

Menurut H. Horne, seorang pendidik dan filosof asal Amerika, pendidikan adalah proses yang terus menerus dari penyesuaian yang lebih tinggi bagi makhluk manusia yang telah berkembang secara fisik dan mental yang bebas dan sadar kepada Tuhan, seperti termanifestasi dalam alam sekitar intelektual, emosional dan kemanusiaan dari manusia.

Jika pernyataan Horne tersebut dimaknai, maka seharusnya siswa yang lebih tinggi bisa memberikan contoh yang baik sehingga siswa yang lebih muda bisa mencontoh kebaikan-kebaikan tersebut dan akan terjadi perpindahan satu kebaikan ke kebaikan yang lain. Pada pernyataan Horne, disebutkan bahwa perkembangan 
fisik dan mental manusia adalah manifestasi dari intelektual, emosional dan kemanusiaan. Apabila budaya kekerasan ini menjadi bagian dari proses pendikan maka kekerasan yang terus berulang merupakan manifestasi dari apa yang selama ini dijalani siswa STIP.

Kasus kematian Amirullah yang menjadi buah bibir di semua media, adalah catatan penting bagi kedinasan yang menaunginya. Pada kasus ini pula media melakukan fungsi sebagai pemberi informasi, dan pemberi kritik sosial kepada instansi terkait untuk segera membenahi diri dalam proses belajar mengajar.

Salah satu media yang aktif memberitakan kasus ini adalah Tempo.co. Portal online dari media Tempo ini pada 11 Januari 2017 memberikan laporan cepat berisi kronologi kematian Amirullah. Dikatakan cepat karena dalam waktu kurang dari 24 jam, berita yang terposting pada pukul 19:51 WIB menceritakan rincian kematian dengan cukup jelas. Maka dalam penelitian ini, penulis memilih pemberitaan media Tempo.co sebagai objek penelitian. Penelitian akan berfokus pada bagaimana Tempo.co mengkonstruksi pemberitaan tentang tewasnya taruna STIP pada berita dengan judul 'Taruna STIP Tewas Dihajar Senior, Ini Kronologinya.' Konstruksi realitas yang dituangkan dalam teks berita tersebut memiliki banyak makna, tidak hanya memberikan informasi kepada masyarakat secara detil tentang kronologis kematian korban, namun Tempo.co juga memberi fungsi kritik dan keberpihakan terkait masalah ini.

Dikutip dari rubrik Riset, Dictum edisi Perdana, April 2007, teks di dalam media adalah hasil proses wacana media (media discourse). Di dalam proses tersebut, nilai-nilai, ideologi, dan kepentingan media turut serta. Hal ini memperlihatkan bahwa media 'tidak netral' sewaktu mengkonstruksi realitas sosial.
Media mengikutsertakan perspektif dan cara pandang mereka dalam menafsirkan realitas sosial. Mereka memilihnya untuk menentukan aspekaspek yang ditonjolkan maupun dihilangkan, menentukan struktur berita yang sesuai dengan kehendak mereka, dari sisi mana peristiwa yang ada disoroti, bagian mana dari peristiwa yang didahulukan atau dilupakan serta bagian mana dari peristiwa yang ditonjolkan atau dihilangkan; siapakah yang diwawancarai untuk menjadi sumber berita, dan lain-lain. Berita bukanlah representasi dari peristiwa semata-mata, akan tetapi di dalamnya memuat juga nilai-nilai lembaga media yang membuatnya (Tuchman, 1991).

Salah satu tindakan itu adalah dalam hal pilihan leksikal dan bahasa (simbol). Sekalipun media massa hanya bersifat melaporkan, tapi jika pemilihan kata, istilah atau simbol yang secara konvensional memiliki arti tertentu di tengah masyarakat, tak pelak akan mengusik perhatian masyarakat. Seperti penggunaan kata 'bullying,' dan 'penganiayaan,' akan menimbulkan anggapan minor tentang kualitas pendidikan di STIP.

Bahasa sebagai alat komunikasi yang dipakai media, mampu mempengaruhi bahkan sampai ke cara melafalkan (pronoun), tata bahasa (grammar), susunan kalimat (syntax), perluasan perbendaharaan kata, dan akhirnya mengubah dan mengembangkan percakapan (speech), bahasa (language) dan makna (meaning). Dengan begitu, penggunaan bahasa tertentu berimplikasi terhadap kemunculan makna tertentu. Pilihan kata dan cara penyajian suatu realitas turut menentukan bentuk konstruksi realitas yang sekaligus menentukan makna yang muncul darinya.

Berangkat dari konsep tersebut, maka teknik analisis yang dianggap mampu membuka makna dari konstruksi berita adalah analisis wacana kritis. Eriyanto (2001) mengatakan bahwa 
analisis wacana kritis adalah salah satu alternatif dari analisis isi selain analisis kuantitatif. Jika analisis kuantitatif lebih menekankan pada pernyataan 'apa' (what) maka analisis wacana lebih menekankan pada 'bagaimana' (how) dari pesan atau teks komunikasi. Melalui analisis wacana kita bukan hanya mengetahui bagaimana isi teks berita, tetapi juga bagaimana pesan itu disampaikan. Dengan melihat bagaimana bangunan struktur kebahasaan tersebut, analisis wacana kritis lebih bisa melihat makna yang tersembunyi dari suatu teks.

Analisis wacana kritis menekankan bahwa wacana adalah juga bentuk interaksi. Norman Faiclough berpendapat bahwa analisis wacana melihat pemakaian bahasa tutur dan tulisan sebagai praktik sosial. Praktik sosial dalam analisis wacana dipandang menyebabkan hubungan yang saling berkaitan antara peristiwa yang bersifat melepaskan diri dari sebuah realitas, dan struktur sosial (Sobur, 2006).

Analisis wacana kritis mempertimbangkan konteks wacana, seperti latar, situasi, peristiwa, dan kondisi. Wacana dalam hal ini diproduksi, dimengerti, dan dianalisis pada suatu konteks tertentu. Merujuk pada pandangan Cook (Badara, 2012: 30), analisis wacana juga memeriksa konteks dari komunikasi: siapa yang mengomunikasikan dengan siapa dan mengapa; dalam jenis khalayak dan situasi apa; melalui medium apa; bagaimana perbedaan tipe dari perkembangan komunikasi; dan hubungan untuk setiap masing-masing. Studi mengenai bahasa di sini memasukkan konteks, karena bahasa selalu berada dalam konteks dan tidak ada tindakan komunikasi tanpa partisipan, interteks, situasi, dan sebagainya. Meskipun demikian, tidak semua konteks dimasukkan dalam analisis, hanya yang relevan dan berpengaruh atas produksi dan penafsiran teks yang dimasukkan ke dalam analisis. Dari keterangan tersebut, maka pemberitaan pada Tempo.co dengan judul 'Taruna STIP Tewas Dihajar Senior, Ini Kronologinya,' akan dianalisis menggunakan teknik analisis wacana kritis untuk melihat bagaimana Tempo.co merangkai informasi sehingga pembaca tidak hanya tahu apa saja yang terjadi tetapi juga diharapkan bisa melihat ketimpangan sistem pendidikan yang ada di STIP.

Pendekatan Fairclough dalam menganalisa teks dianggap lengkap karena berusaha menyatukan tiga tradisi yaitu;

1. Dimensi Tekstual (Mikrostruktural), meliputi: kohesi dan koherensi, tata bahasa, dan diksi.

2. Dimensi Kewacanaan (Mesostruktural), meliputi: produksi teks, penyebaran teks dan konsumsi teks.

3. Dimensi Praktik Sosial-Budaya (Makrostruktural), meliputi: situasional, institusional dan sosial.

Penelitian ini akan mengambil ketiga dimensi tersebut untuk melihat hasil yang menyeluruh dari bagaimana Tempo.co melakukan kontruksi realitas yang tertuang pada teks berita 'Taruna STIP Tewas Dihajar Senior, Ini Kronologinya.'

\section{Metodologi}

Penelitian ini termasuk dalam jajaran penelitian kualitatif. Penelitian kualitatif adalah riset yang bersifat deskriptif dan cenderung menggunakan analisis dengan pendekatan induktif. Proses dan makna (perspektif subyek) lebih ditonjolkan dalam penelitian kualitatif. Landasan teori dimanfaatkan sebagai pemandu agar fokus penelitian sesuai dengan fakta di lapangan. Selain itu landasan teori juga bermanfaat untuk memberikan gambaran umum tentang latar belakang penelitian dan sebagai bahan pembahasan hasil penelitian.

Paradigma penelitian ini adalah paradigma kritis. Everett M. Roger, seperti dikutip oleh Eriyanto (2001), mengemukakan bahwa 'media bukanlah entitas yang netral, tetapi bisa dikuasai 
oleh kelompok dominan.' Paradigma kritis percaya bahwa media adalah sarana di mana kelompok dominan dapat mengontrol kelompok yang tidak dominan, bahkan memarjinalkan mereka dengan menguasai dan mengontrol media. Sehingga jawaban yang diharapkan dari pertanyaan-pertanyaan tersebut adalah adanya kekuatan-kekuatan yang berbeda dalam masyarakat yang mengontrol suatu proses komunikasi. Jika dalam kasus kematian taruna STIP ini pihak korban dianggap sebagai kelas dominan karena mereka adalah korban yang harus mendapatkan pembelaan, maka pihak pelaku dan juga STIP sebagai institusi tempat kekerasan tersebut terjadi menduduki kelas yang relatif termarjinalkan.

Pada paradigma kritis, penelitian media massa lebih diletakkan dalam kesadaran bahwa teks atau wacana dalam media massa mempunyai pengaruh yang sedemikian rupa pada manusia. Seluruh aktivitas dan pemaknaan simbolik dapat dilakukan dalam teks media massa. Teks dalam media massa dipandang bukan realitas yang bebas nilai. Pada titik kesadaran pokok manusia, teks selalu memuat kepentingan. Teks pada prinsipnya telah diambil sebagai realitas yang memihak. Tentu saja teks dimanfaatkan untuk memenangkan pertarungan ide, kepentingan atau ideologi tertentu kelas tertentu. Pada titik tertentu, teks media pada dirinya bersifat ideologis (Littlejohn dan Foss, 2011:183-217).

\section{Hasil dan Pembahasan}

\begin{tabular}{|c|c|}
\hline Jenis Media & \multicolumn{1}{|c|}{ Online } \\
\hline Nama Media & \multicolumn{1}{|c|}{ Tempo.co } \\
\hline Judul & $\begin{array}{c}\text { Senior, Ini Kronologinya. } \\
\text { Rabu, 11 Januari 2017, pukul } \\
\text { Terbit }\end{array}$ \\
\hline Isi & $\begin{array}{l}\text { TEMPO.CO, Jakarta - Seorang } \\
\text { siswa tingkat satu di Sekolah } \\
\text { Tinggi Ilmu Pelayaran, Jakarta } \\
\text { Utara, bernama Amirulloh }\end{array}$ \\
\hline
\end{tabular}

Adityas Putra, 18 tahun, meninggal dunia setelah dianiaya oleh empat seniornya di dalam asrama, Selasa malam, 10 Januari 2017. Ini kronologi penganiayaan sadis yang dilakukan empat senior itu kepada juniornya.

"Pelaku menganiaya korban dengan cara memukul perut, dada, dan ulu hati dengan tangan kosong," kata Kepala Humas Polres Metro Jakarta Utara, Komisaris M. Sungkono kepada wartawan pada Rabu, 11 Januari 2017.

Amirulloh diketahui meninggal pada Selasa malam sekitar pukul 22.30 WIB di dalam asrama. Korban dipukuli oleh empat terduga pelaku yakni Sisko Mataheru (19), Willy Hasiholan (20), Iswanto (21), dan Akbar Ramadhan (19). Para senior tahun kedua ini, tidak hanya menyiksa Amirulloh, tapi juga lima taruna tingkat pertama lain.

Menurut Sungkono, tindakan sadis senior, yang tampaknya biasa dilakukan pada juniornya, digagas oleh Sisko. Ia mengungkapkan renananya untuk mem-bully juniornya itu pada ketiga rekannya setelah latihan drum band.

Sekitar pukul 22.00, empat sekawan ini memanggil korbannya: enam junior yang belum satu semester menjadi taruna di sekolah pelayaran milik Kementerian Perhubungan ini. Mereka diminta berkumpul di Lantai 2, kamar M-205, Gedung Dermotery Ring 4.

Keenam junior diminta berdiri berjajar dan para senior mulai prosesi bully mereka. Empat pelaku bergantian menghajar junior di bagian dada, ulu hati dan perut. Masing-masing korban mendapat serangkaian pukulan dari empat 


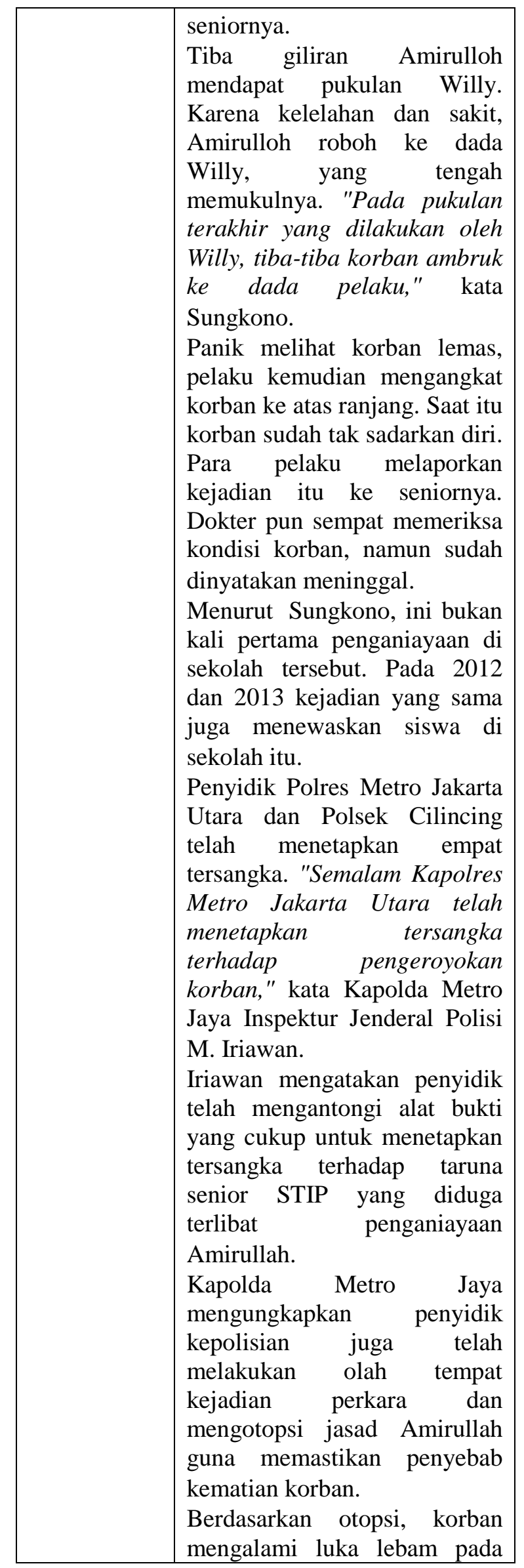

\begin{tabular}{|c|}
\hline 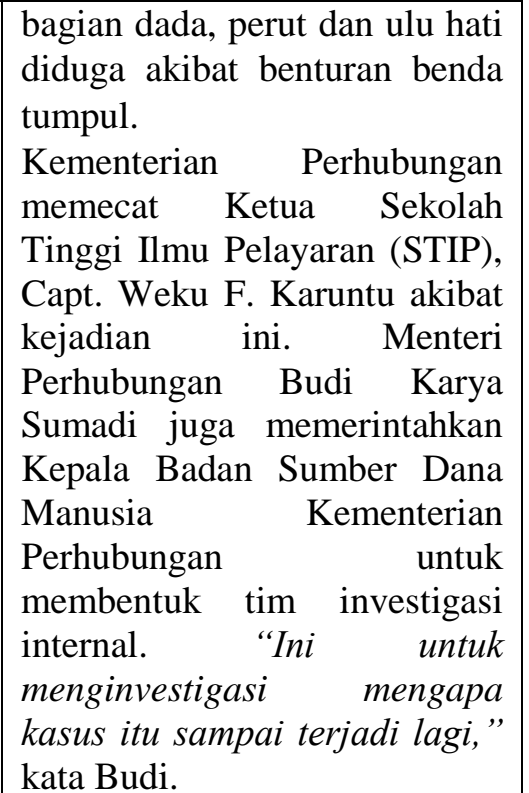 \\
\hline
\end{tabular}

Tabel 1. Objek Penelitian

a. Analisis Mikrostruktural

Berdasarkan berbagai alat kebahasaan yang digunakan Tempo.co dalam pemberitaan 'Taruna STIP Tewas Dihajar Senior, Ini Kronologinya' terdapat tiga alat yang menandai representasi tema dan tokoh, yang teribat dalam pemberitaan tersebut di atas. Yaitu melalui diksi, penggunaan kalimat sebab-akibat, dan pemilihan narasumber dalam kutipan langsung. Dari judul sudah terlihat pemilihan diksi tewas dan dihajar yang memiliki makna semantik sebab-akibat, yang artinya ada kekerasan yang mengakibatkan meregangnya nyawa seseorang. Selanjutnya, di bawah ini adalah analisis dari aspek kebahasaan dari paragraf-paragraf teks berita tersebut:

(1) Seorang siswa tingkat satu di Sekolah Tinggi Ilmu Pelayaran, Jakarta Utara, bernama Amirulloh Adityas Putra, 18 tahun, meninggal dunia setelah dianiaya oleh empat seniornya di dalam asrama, Selasa malam, 10 Januari 2017.

(2) Para senior tahun kedua ini, tidak hanya menyiksa Amirulloh, tapi juga lima taruna tingkat pertama lain.

Data (1) sampai (2): menandai bahwa untuk kasus dalam konteks yang sama, Tempo.co cermat dalam membedakan diksi yang digunakan untuk menunjukkan status dari tokoh. Kedua 
diksi tersebut memiliki makna semantik yang berlainan pula. Secara semantik leksikal, makna kata siswa menunjukkan status tokoh pertama (korban) sebagai pelajar, namun pada tokoh kedua (pelaku) digunakan kata senior yang lebih menunjukkan status seseorang dengan pangkat lebih tinggi dari orang lain namun belum tentu sama-sama siswa. Kemudian pada pemilihan kata tingkat satu menunjukkan bahwa tokoh pertama adalah siswa yang masih rendah posisinya.

Pada kata tahun kedua lebih menunjukkan pada masa pendidikan yang telah dtempuh tokoh kedua. Hal ini menunjukkan perbedaan bahwa penyebutan tokoh pertama sebagai siswa tingkat satu merepresantikan siswa tingkat dasar sebuah institusi pendidikan. Namun penyebutan tokoh kedua lebih merepresentasikan senior/seseorang yang dituakan, yang sudah berpengalaman dua tahun, dan belum tentu siswa. Dengan kata lain, Tempo.co menggunakan kata ganti untuk membedakan secara jelas status dari tokoh pertama dan tokoh kedua, meskipun mereka sama-sama taruna STIP.

(3) "Pelaku menganiaya korban dengan cara memukul perut, dada, dan ulu hati dengan tangan kosong," kata Kepala Humas Polres Metro Jakarta Utara, Komisaris M. Sungkono kepada wartawan.

(4) Para senior tahun kedua ini, tidak hanya menyiksa Amirulloh, tapi juga lima taruna tingkat pertama lain.

(5) Sungkono, tindakan sadis senior, yang Menurut tampaknya biasa dilakukan pada juniornya, digagas oleh Sisko. Ia mengungkapkan renananya untuk membully juniornya itu pada ketiga rekannya setelah latihan drum band.

Dari data (3) sampai (5): menandai bahwa Tempo.co mengambil pernyataan narasumber dengan menggunakan diksi lengkap tentang sesuatu yang buruk, yakni: menganiaya, menyiksa, sadis, dan membully sebagai kata ganti dari tindakan yang dilakukan oleh tokoh kedua. Menganiaya diartikan sebagai memperlakukan dengan sewenang-wenang (seperti menyiksa dan menyakiti), meskipun mungkin tokoh kedua sebagai senior punya alasan sendiri dalam mendidik tokoh pertama. Bisa saja kekerasan struktural sudah menjadi bagian dari sistem pendidikan di STIP dan tidak ada maksud menganiaya dari tokoh kedua.

Menyiksa digunakan sebagai kata ganti tindakan yang dilakukan tokoh kedua. Menyiksa diartikan sebagai menghukum dengan menyengsarakan (menyakiti, menganiaya); berbuat dengan menyengsarakan (menyakiti, menganiaya); berbuat bengis kepada yang lain dengan menyakiti (menganiaya dan sebagainya). Diksi ini merepresentasikan bahwa yang dilakukan tokoh kedua sangat kejam dan tanpa pembenaran didalamnya.

Sadis digunakan sebagai kata ganti yang menunjukan bagaimana (how) proses pemukulan itu terjadi. Sadis memiliki arti: tidak mengenal belas kasihan, kejam, buas, ganas, kasar. Kata sadis tidak hanya merepresentasikan sebuah tindakan, namun dia juga menunjuk kata benda atau orang yang berarti orang yang sadis. Tempo.co dengan kata lain, menyebut tokoh kedua melakukan tindakan sadis dan juga tokoh kedua adalah orang yang sadis.

Mem-bully digunakan sebagai pelengkap dari kata ganti yang menunjukkan perilaku tokoh kedua. $\mathrm{Mem}$ bully diartikan sebagai perilaku agresif disengaja yang menggunakan ketidakseimbangan kekuasaan atau kekuatan. Maka kata mem-bully menjadi penegasan dari data (1) dan data (2) bahwa terjadi perilaku agresif yang sadis, dengan cara menganiaya, menyiksa dan membully kepada tokoh pertama yang menempati struktur bawah (siswa tingkat satu) yang dilakukan oleh tokoh kedua yang menempati struktur diatasnya (senior tahun kedua).

(6) Sekitar pukul 22.00, empat sekawan ini memanggil korbannya: enam junior yang belum satu semester menjadi taruna di sekolah pelayaran milik Kementerian 
Perhubungan ini. Mereka diminta berkumpul di Lantai 2, kamar M-205, Gedung Dermotery Ring 4.

Data (6) menandai bahwa Tempo.co melakukan penegasan dengan menyebutkan nama instansi tempat kejadian berlangsung. Kata ini bisa dimaknai sebagai identitas tempat, sekaligus membawa pembaca pada kesimpulan bahwa telah terjadi kekerasan di lingkup pendidikan kedinasan di bawah Kemeterian Perhubungan.

(7) Keenam junior diminta berdiri berjajar dan para senior mulai prosesi bully mereka. Empat pelaku bergantian menghajar junior di bagian dada, ulu hati dan perut. Masing-masing korban mendapat serangkaian pukulan dari empat seniornya.

(8) Tiba giliran Amirulloh mendapat pukulan Willy. Karena kelelahan dan sakit, Amirulloh roboh ke dada Willy, yang tengah memukulnya. "Pada pukulan terakhir yang dilakukan oleh Willy, tibatiba korban ambruk ke dada pelaku," kata Sungkono.

(9) Panik melihat korban lemas, pelaku kemudian mengangkat korban ke atas ranjang. Saat itu korban sudah tak sadarkan diri. Para pelaku melaporkan kejadian itu ke seniornya. Dokter pun sempat memeriksa kondisi korban, namun sudah dinyatakan meninggal.

Data (7) sampai data (9) merupakan contoh data pemanfaatan strategi linguistik yang berupa struktur kalimat sebab-akibat. Kalimat luas pada data (8) di atas memiliki hubungan sebab-akibat yang ditandai dengan konjungsi karena yang menggabungkan antara sebab pada data (7) dan akibat pada data (9).

(10) Menurut Sungkono, ini bukan kali pertama penganiayaan di sekolah tersebut. Pada 2012 dan 2013 kejadian yang sama juga menewaskan siswa di sekolah itu.

Data (10) menandai adanya usaha penyisipan informasi dari narasumber yang membuat pembaca mengerti bahwa kekerasan di STIP bukan baru terjadi kali ini. Diksi sama merupakan pemanfaatan strategi linguistik berupa struktur kata yang memiliki hubungan sederajat.

(11) Penyidik Polres Metro Jakarta Utara dan Polsek Cilincing telah menetapkan empat tersangka. "Semalam Kapolres Metro Jakarta Utara telah menetapkan tersangka terhadap pengeroyokan korban," kata Kapolda Metro Jaya Inspektur Jenderal Polisi M Iriawan.

(12) Iriawan mengatakan penyidik telah mengantongi alat bukti yang cukup untuk menetapkan tersangka terhadap taruna senior STIP yang diduga terlibat penganiayaan Amirullah.

(13) Kapolda Metro Jaya mengungkapkan penyidik kepolisian juga telah melakukan olah tempat kejadian perkara dan mengotopsi jasad Amirullah guna memastikan penyebab kematian korban.

(14) Berdasarkan otopsi, korban mengalami luka lebam pada bagian dada, perut dan ulu hati diduga akibat benturan benda tumpul.

Data (11) sampai data (14) menandai pemilihan narasumber sebagai pendukung teks berita. Narasumber yang dihadirkan dalam berita ini adalah dua orang dari kepolisian, dari Humas Polda Metro Jaya dan Kapolda Metro Jaya. Padahal tema dalam berita adalah kronologi kematian tokoh pertama. Maka seharusnya dilakukan penulisan secara cover both side, antara pihak dari tokoh pertama, keterangan pihak tokoh kedua, STIP dan kepolisian. Namun dalam pemilihan narasumber dan kutipan narasumber yang dipilih semuanya menunjuk pada satu hal, bahwa kematian taruna STIP tersebut adalah tindakan fatal yang tidak perlu mendapat alasan dari sudut pandang manapun.

Kata pengeroyokan oleh narasumber diperkuat dengan kata penganiayaan oleh keterangan Tempo.co. Pengeroyokan memiliki makna penyerangan objek secara bersama-sama dengan cara yang brutal dan tidak adil, maka penganiayaan menjadi 
pelengkap kata pengeroyokan yang dikatakan oleh narasumber. Sedangkan kalimat memastikan penyebab kematian korban adalah perluasan struktur bahasa yang berkedudukan sebagai klausa akibat dari kata pengeroyokan dan penganiayaan. Kalimat mengalami luka lebam pada bagian dada, perut dan ulu hati diduga akibat benturan benda tumpul selanjutnya menjadi pelengkap dari klausa memastikan penyebab kematian korban.

Pemilihan narasumber dan interpretasi pesan dalam teks berita ini menunjukan bahwa terdapat praktik konstruksi realitas, seperti dikatakan sebelumnya, media mampu menentukan aspek-aspek yang ditonjolkan maupun dihilangkan dari sebuah berita, menentukan struktur berita yang sesuai dengan kehendak mereka, dan dari sisi mana peristiwa yang ada akan disoroti.

(15) Kementerian Perhubungan memecat Ketua Sekolah Tinggi Ilmu Pelayaran (STIP), Capt. Weku F. Karuntu akibat kejadian ini. Menteri Perhubungan Budi Karya Sumadi juga memerintahkan Kepala Badan Sumber Dana Manusia Kementerian Perhubungan untuk membentuk tim investigasi internal. "Ini untuk menginvestigasi mengapa kasus itu sampai terjadi lagi," kata Budi.

Data (15) menandai pemanfaatan strategi penyusunan paragraf dan penonjolan informasi, dari sekian banyak paragraf dalam teks berita 'Taruna STIP Tewas Dihajar Senior, Ini Kronologinya' maka keterangan dari pihak Kementrian Perhubungan diletakan pada akhir berita. Jika dianalisis menggunakan teknik piramida terbalik, maka paragraf tersebut menunjukan bahwa keterangan yang terdapat didalamnya memiliki derajat kepentingan yang rendah. Dari laman panduanjurnalistik.wordpress.com

dikatakan bahwa manfaat utama dari struktur piramida terbalik berkait dengan space atau ruang dalam halaman yang disediakan untuk memuat berita. Ketika berita itu terlalu panjang dan tidak cukup untuk dimuat di halaman yang disediakan, maka editor bisa saja membuang bagian berita itu mulai dari paling bawah atau derajat informasi pentingnya yang paling rendah yang biasanya diletakan di bagian bawah atau akhir berita.

b. Analisis Mesostruktural

Dalam analisis dimensi ini, penafsiran dilakukan terhadap pemprosesan wacana yang meliputi aspek penghasilan, penyebaran, dan penggunaan teks. Beberapa dari aspek itu memiliki karakter yang lebih institusi, sedangkan yang lain berupa proses-proses penggunaan dan penyebaran wacana. Berkenaan dengan proses-proses institusional, Fairclough merujuk rutinitas institusi seperti prosedur-prosedur editor yang dilibatkan dalam penghasilan teksteks media. Praktik wacana meliputi caracara para pekerja media memproduksi teks. Melalui analisis wacana kita bukan hanya mengetahui bagaimana isi teks berita, tetapi juga bagaimana pesan itu disampaikan.

Tempo.co (sebelumnya bernama Tempointeraktif) ialah sebuah halaman web berita dan artikel dalam jaringan yang didirikan oleh PT. Tempo Inti Media, Tbk. Didirikan pada tahun 1996 oleh Yusril Djalinus, Bambang Bujono, S. Prinka, dan Saiful B. Ridwan dengan nama Tempointeraktif. Sebelumnya, PT Tempo Inti Media, Tbk. telah melahirkan majalah mingguan Tempo yang mengalami pemberedelan selama dua kali pada masa Orde Baru. Geliat Kelompok Tempo Media setelah mengalami pemberedelan dimulai dengan pembuatan situs Tempointeraktif, yang akhirnya menjadi pionir berita internet di Indonesia.

Sejalan dengan PT. Tempo Inti Media, maka visi dari Tempo.co adalah menjadi media acuan dalam usaha meningkatkan kebebasan publik untuk berpikir dan berpendapat serta membangun peradaban yang menghargai kecerdasan dan perbedaan. Sedangkan misi-nya adalah: 
- Menghasilkan produk multimedia yang independen dan bebas dari segala tekanan dengan menampung dan menyalurkan secara adil suara yang berbeda-beda.

- Menghasilkan produk multimedia bermutu tinggi dan berpegang pada kode etik.

- Menjadi tempat kerja yang sehat dan menyejahterakan serta mencerminkan keragaman Indonesia.

- Memiliki proses kerja yang menghargai dan memberi nilai tambah kepada semua pemangku kepentingan.

- Menjadi lahan kegiatan yang memperkaya khazanah artistik, intelektual, dan dunia bisnis melalui pengingkatan ideide baru, bahasa, dan tampilan visual yang baik.

- Menjadi pemimpin pasar dalam bisnis multimedia dan pendukungnya.

Berdasarkan uraian di atas dapat diketahui bahwa sebagai media, Tempo.co merupakan harian umum daring yang dapat mempengaruhi opini masyarakat Indonesia dengan cukup luas. Rangkaian produksi teks di Tempo.co bukan hanya merupakan rangkaian yang berdiri sendiri, tetapi merupakan rangkaian institusional yang melibatkan wartawan, redaksi, editor, dan lain-lain. Realisasi teks yang dihasilkan Tempo.co khususnya dalam hal pemberitaan 'Taruna STIP Tewas Dihajar Senior, Ini Kronologinya,' dinilai selaras dengan misi yang disebutkan yaitu, menghasilkan produk multimedia yang independen dan bebas dari segala tekanan dengan menampung dan menyalurkan secara adil suara yang berbeda-beda. Tempo.co dalam teks nya tidak memihak pada institusi pemerintahan yang besar, namun pada pihak korban.

c. Analisis Makrostruktural

Dimensi ketiga merupakan analisis tingkat makro yang didasarkan pada pendapat bahwa konteks sosial yang ada di luar media sesungguhnya mempengaruhi bagaimana wacana yang ada dalam media. Ruang redaksi atau wartawan bukanlah bidang atau ruang kosong yang steril, tetapi juga sangat ditentukan oleh faktorfaktor di luar media itu sendiri. Praktik sosial-budaya menganalisa tiga hal yaitu ekonomi, politik (khususnya berkaitan dengan isu-isu kekuasaan dan ideologi) dan budaya (khususnya berkaitan dengan nilai dan identitas) yang juga mempengaruhi istitusi media, dan wacananya. Pembahasan praktik sosial budaya meliputi tiga tingkatan. Tingkat situasional, berkaitan dengan produksi dan konteks situasinya. Tingkat institusional, berkaitan dengan pengaruh institusi secara internal maupun eksternal. Tingkat sosial, berkaitan dengan situasi yang lebih makro, seperti sistem politik, sistem ekonomi, dan sistem budaya masyarakat secara keseluruhan. Tiga tingkat analisis dalam pemberitaan 'Taruna STIP Tewas Dihajar Senior, Ini Kronologinya,' antara lain:

Tingkat situasional. Kekerasan dalam dunia pendidikan merupakan hal yang berulang kali terjadi, maka kematian taruna STIP karena kelalaian senior dan kurangnya keamanan dari dalam institusi terkait, menjadi alarm sosial bagi seluruh lapisan masyarakat. Bagaimana di luar jam belajar mengajar ternyata terdapat tradisi kekerasan yang berulang. Pihak institusi STIP dengan kasus ini diharapkan mampu berbenah, mengingat ini bukan kasus pertama, dengan tidak lagi membiarkan kekerasan menjadi bagian dari hubungan antarpersonal antara senior dan junior, juga tidak mengidentikan kedisiplinan dengan kekerasan struktural. Peristiwa ini menjadi perhatian bagi banyak media, termasuk didalamnya Tempo.co.

Tingkat institusional. Penulisan teks berita pada 'Taruna STIP Tewas Dihajar Senior, Ini Kronologinya,' melibatkan narasumber dari pihak kepolisian sebanyak dua orang, yaitu Kepala Humas Polres Metro Jakarta Utara, Komisaris M. Sungkono; Kapolda Metro Jaya Inspektur Jenderal Polisi M Iriawan; Menteri Perhubungan Budi Karya Sumadi. Diharapkan dengan pemilihan narasumber 
dari institusi kepolisian dan kementrian perhubungan tersebut, pembaca bisa lebih meyakini tema yang diangkat oleh Tempo.co bahwa terdapat lagi kasus kekerasan dalam pendidikan, dan pihak korban harus mendapat keadilan.

Tingkat sosial. Dapat ditarik benang merah bahwa pemberitaan yang dihasilkan oleh Tempo.co erat kaitannya dengan eksistensi media itu sendiri dalam menghapuskan praktik kekerasan dan senioritas di dalam Lembaga Pendidikan Tinggi Kedinasan, khususnya STIP. Ada motivasi tertentu dalam pemberitaan yang dicitrakan Tempo.co. Keberpihakan Tempo.co pada korban dan tema kronologi namun kurang cover both side, secara tidak langsung menuntun masyarakat pada pemahaman bahwa kekerasan pendidikan dalam bentuk apapun tidak memiliki ruang pembenaran. Dengan demikian, opini pembaca digiring untuk memberikan pencitraan positif pada Tempo.co sebagai media yang aktif dan eksis dalam menyuarakan usaha mencapai keadilan bagi ketimpangan yang terjadi di berbagai sistem masyarakat.

\section{Penutup}

Analisis wacana kritis menekankan bahwa wacana adalah juga bentuk interaksi. Norman Faiclough berpendapat bahwa analisis wacana melihat pemakaian bahasa tutur dan tulisan sebagai praktik sosial. Praktik sosial dalam analisis wacana dipandang menyebabkan hubungan yang saling berkaitan antara peristiwa yang bersifat melepaskan diri dari dari sebuah realitas, dan struktur sosial. Dari berbagai alat kebahasaan yang digunakan Tempo.co dalam pemberitaan 'Taruna STIP Tewas Dihajar Senior, Ini Kronologinya' terdapat tiga alat yang menandai representasi tema dan tokoh yang terlibat. Yaitu melalui diksi, penggunaan kalimat luas sebab akibat, dan pemilihan narasumber dalam kutipan langsung. Rangkaian produksi teks di Tempo.co juga merupakan rangkaian institusional yang melibatkan wartawan, redaksi, editor, dan lain-lain.

Realisasi teks yang dihasilkan Tempo.co dalam pemberitaan tersebut juga dinilai selaras dengan misi-nya yaitu menghasilkan produk multimedia yang independen dan bebas dari segala tekanan dengan menampung dan menyalurkan secara adil suara yang berbeda-beda. Ada motivasi tertentu dalam pemberitaan tersebut dalam pencitraan Tempo.co. Opini pembaca digiring untuk memberikan pencitraan positif pada Tempo.co sebagai media yang aktif dan eksis dalam menyuarakan keadilan bagi ketimpangan yang terjadi di berbagai sistem yang ada di masyarakat.

\section{Daftar Pustaka}

Badara, A. (2012). Analisis Wacana: Teori, Metode, dan Penerapannya pada Wacana Media. Jakarta: Kencana Prenada Media Group.

Eriyanto. (2001). Analisis Wacana: Pengantar Analisis Teks Media. Yogyakarta: LKiS.

Littlejohn, S. W. \& Foss, K. A. (2011). Theories of Human Communication. Illionis: Waveland Press.

Sobur, A. (2006). Analisis Teks Media. Bandung: Remaja Rosdakarya.

Tuchman, G. (1991). Qualitative Method in the Study of News, dalam Jensen, K. B. \& Jankowski, N. W. (ed.), A Handbook of Qualitative Methodologies for Mass Communication Research. London and New York: Routledge.

https://dictum4magz.wordpress.com/2007/ 12/04/menyelami-analisis-wacanamelalui-paradigma-kritis/

https://panduanjurnalistik.wordpress.com/ 2014/03/07/235/ 